\title{
The Development of Teaching Materials Based on Local Assistance in the Appreciation Materials of Indonesian Education Students UHKBPNP
}

\author{
Monalisa Frince $\mathbf{S}^{\mathbf{1}}$, Marlina A Tambunan ${ }^{2}$ \\ ${ }^{1,2}$ Indonesian Language Education, HKBP Nommensen Pematangsiantar, Indonesia \\ sianturimonalisa@gmail.com,marlinatambunan71@gmail.com
}

\begin{abstract}
This study aims to determine: (1) the development of teaching materials based on local wisdom on prose appreciation materials, (2) the appropriateness of teaching materials based on local wisdom on prose appreciation materials. This type of research is research and development based on the Borg and Gall development model. The trial subjects consisted of material experts, design experts, Indonesian language education lecturers, and Indonesian language education students. Data about the quality of this product were collected through questionnaires and tests to appreciate prose by writing short stories. The results of this study indicate that: (1) material validation includes content eligibility with an average of $93.75 \%$ on very good criteria, presentation feasibility with an average of $91.34 \%$ on very good criteria, language eligibility with an average of $95,19 \%$ on very good criteria, (2) validation of design experts with an average of $92.08 \%$ on very good criteria, (3) individual trials with an average of $82.50 \%$ with very good criteria, (4) small group trials with an average of 90,27\% with very good criteria, and (5) limited field group test with an average of $94.02 \%$ with very good criteria. Thus, the module based on local wisdom on prose appreciation material that has been developed is suitable for use as a learning resource.
\end{abstract}

Keywords development; local wisdom; appreciation of prose

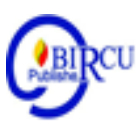

\section{Introduction}

Independent teaching materials play an important role in supporting the main teaching materials. Good independent teaching materials are teaching materials that are able to enable students to achieve goals, learning outcomes and can be understood with or without lecturers. One form of independent teaching material is a module. Daryanto (2013: 9), states that the module isa form of teaching material that is packaged in a comprehensive and systematic manner, which contains a set of planned learning experiences designed to help students master specific learning goals. In line with this Depdiknas (2008: 20), states that a module is a set of teaching materials that are presented systematically so that its use can be studied with or without a facilitator or lecturer.

The Covid-19 pandemic situation is currently sweeping the world and including Indonesia. Learning and teaching must be done online so the module is the right choice to be developed so that students are able to understand and learn on their own even though they are not face to face with lecturers. This is in accordance with the objectives of making the module itself, as stated by Prastowo (2015: 108), that in making the module has several objectives: 1) so that students can learn independently without or with the guidance of 
lecturers; 2) so that the role of lecturers is not too dominant in learning activities; 3) train student honesty; and 4) accommodate various levels and speeds of student learning. By using modules as independent teaching materials, students can train themselves to be honest and more dominant in learning activities.

One of the independent teaching materials that will be developed is prose appreciation materials taught by researchers in odd semesters. Researchers found bbased on the results of preliminary observations there are obstacles in learning literary appreciation, especially in prose appreciation material. In the Indonesian Language Education study program, the Literary Appreciation course is a compulsory subject. It was found in the field that showed that the material on prose appreciation in this subject did not get a positive response from students as seen from the level of appreciation and value acquisition. Based on student responses, they are only able to enjoy prose level. Meanwhile, according to literary scholars in general, the level of literary appreciation consists of four, namely: the level of enjoying, enjoying, enjoying, and producing. Then, the average score of students in appreciating prose is 65 or about $45 \%$ of the 52 total students in the second semester of the 2018/2019 academic year.

\section{Review of Literatures}

Students also seem to have a dependency on direct lecturer instructions so that independent teaching materials are needed to support the textbooks used by students. The main source of textbooks used by students contains theories about the appreciation of prose so that independent supporting teaching materials are needed on prose appreciation material. As lecturers, researchers have also planned to design independent teaching materials to help students with prose appreciation material. Through this research, independent teaching materials designed will be validated and can be used to help answer problems that occur. According to research(Ferdianto \& Setiyani, 2018), lecturers are expected to be able to process, design teaching materials based on the objectives and needs that are in accordance with the learning conditions, given the freedom to design and determine their own learning materials according to the cultural model in which they teach. Lecturers can make teaching materials that can answer students' needs for the learning process of prose appreciation material.

The importance of teaching materials in learning activities can be analogous to the importance of a hoe or plow tool. (Lubis, 2020). The initial needs analysis will describe how much student needs in helping learning outcomes in prose appreciation material. The design of teaching materials must be in accordance with the needs of students and be close to the life of the student environment. This is in accordance with the demands of the KKNI curriculum used, which is close to the real life of students so that it is easy to understand the material.

The real thing that is close to the direct life of students, one of which lies in the culture of local wisdom that surrounds student life. The cultural background and area of residence in the surrounding Pematangsiantar area is Batak Simalungun. Compiled from the Pematangsiantar city government website, Pematangsiantar is one of the cities in North Sumatra Province which has an area of $79,9706 \mathrm{~km}^{2}$ consists of 8 (eight) districts and 53 (fifty three) villages. Previously it was part of the Simalungun district area and officially changed to a city in 1965. That is why the majority of the population in Pematangsiantar city is generally the Simalungun Batak tribe, then the Toba Batak, Karo, Javanese, Mandailing, Chinese and others. 
Culture in Pematangsiantar is "marsipasangapan" or respect and upholds tolerance. This is evidenced by the slogan of the city of Pematangsiantar "Sapangambei Manoktok Hitei" which means working together for one purpose. Even though they have different ethnic and religious backgrounds, they still respect and uphold tolerance for a common goal. Therefore, Pematangsiantar city is known as the most tolerant city in Indonesia.

This "marsipasangapan" culture should be known and preserved by the scientific community, especially students of the Indonesian Language Education study program, HKBP Nommensen University Pematangsiantar in Pematangsiantar city. This culture is a form of local wisdom that has a high background and noble values. In addition, there are many local wisdoms in the form of fairy tales and legends which are translated into Indonesian. Then, short stories and novels made by local people which carry the theme of culture in the city of Pematangsiantar.

Law of the Republic of Indonesia No. 32 of 2009 on Environmental Protection and Management states "Local wisdom is noble values that apply in the order of community life, among others, to protect and manage the environment in a sustainable manner." Etymologically, local wisdom consists of two words, namely wisdom and local which is also called local knowledge. The scope of local wisdom is wide enough that it is difficult to limit it. Local wisdom emphasizes the locality of wisdom that is passed down from generation to generation. However, it also does not rule out local wisdom that is created from interactions with people from other cultures. Local wisdom is also a product of past culture which is continuously used as a guide for living in sustainable community life.

Local wisdom can be used as the basis for developing independent teaching materials that are close to student life. Local wisdom can be interpreted as noble values contained in traditions and culture, proverbs, and life motto. Rahyono (2009: 9) states that the factors that make local wisdom have a strategic position in learning are: (1) local wisdom is a form of identity from birth; (2) local wisdom is not foreign to the owner; (3) local wisdom is able to elevate the dignity of the nation.

According to Sugiharto (2020) education is one of the efforts to improve the ability of human intelligence, thus he is able to improve the quality of his life. Education is the most important thing for the development of a nation's civilization. In setting up a stable education system, of course, it takes a long and tiring process to achieve high quality standards (Junifran, 2020). The learning achievement in prose appreciation material is that students are able to enjoy, enjoy, react, and produce old prose and new prose such as: fairy tales, legends, short stories and novels. Local wisdom can be used as a motivator for students to learn to value and appreciate literature through the process of learning prose appreciation material. Prose consists of short stories, novels and other fictional stories with local wisdom as the basis and all of this is poured into an independent teaching material in the form of modules used to help students learn to appreciate prose. This study aims to produce an independent teaching material product in the form of a module based on local wisdom on prose appreciation material. 


\section{Research Method}

The research method used is the method of research and development or Research \& Development (R\&D). Research and development methods are methods used to produce a product and test the product's feasibility in accordance with development objectives. The product produced from this research and development is the Appreciation Prose learning module based on local wisdom. The methods used include descriptive and evaluative methods. Descriptive method to describe the preparation of teaching materials according to student conditions. Evaluative method to evaluate the feasibility of implementing Prose Appreciation teaching materials based on local wisdom. This type of research is development research, namely the development of teaching materials based on local wisdom on Prose Appreciation Materials. This development research refers to the theory of teaching material development put forward by Borg and Gall (in Tegeh, et al. 2014) in the book Development Research Methods.

\section{Discussion}

\subsection{Compilation of Local Wisdom-Based Teaching Materials on Prose Appreciation Material}

Based on the results of research that has been carried out by distributing a needs analysis questionnaire to 36 students, the preparation of teaching materials in the form of modules based on local wisdom on prose appreciation material is as follows.

1. Teaching materials are arranged in the form of modules that help students learn independently on prose appreciation material. The data found, as many as 36 students with a percentage of $100 \%$ said they needed a prose appreciation writing module. Teaching materials for prose appreciation materials are compiled containing information on local wisdom in Pematangsiantar in accordance with the context of life around students. The data found, as many as 36 students with a percentage of $100 \%$ stated that they needed teaching materials that contained local wisdom. Teaching materials are prepared by integrating local wisdom into prose appreciation materials consisting of folk tales, short stories, novels, and others. The data found, as many as 33 students with a percentage of $91 \%$ stated that local wisdom-based teaching materials can help students appreciate prose.

2. Teaching materials are prepared with student learning outcomes being able to appreciate prose by writing short stories based on local wisdom. Learning outcomes are contained in the syllabus and RPS used. Teaching materials are prepared based on local wisdom in Pematangsiantar City. As many as 36 students with a percentage of $100 \%$ said they needed teaching materials in the form of modules in appreciating prose. Teaching materials are prepared based on Learning Outcomes with the title "Appreciation of Prose Based on Local Wisdom" contains: 1) introduction, 2) table of contents, 3) map of module position, 4) introduction, 5) learning activities consisting of: objectives, description of material summary, assignments, and worksheets, 6) evaluation, 7) answer keys, 8) glossary, 9) bibliography.

3. Based on the feasibility aspect of the content, students need independent teaching materials that contain: a) the material sources used are local wisdom in Pematangsiantar city, books, and the internet; b) the material coverage includes, the understanding of the appreciation of prose, fairy tales, legends, short stories, novels, 
and others; c) There are learning instructions that serve as instructions for the use of independent teaching materials so that students are more focused; d) Learning outcomes that function for students to know the achievements that must be met in teaching materials; e) The characteristics of the teaching materials needed by students are materials that are easy to understand and broaden their knowledge so as to motivate students to appreciate prose; f) The contents of the material needed by students include examples, assignments, multiple choice tests, and independent worksheets; and g) Elements of noble values,

4. Based on the feasibility aspect of presenting the material, students need independent teaching materials which contain: a) The systematic and complete presentation of the material; b) There are instructions for using independent teaching materials; c) Presentation of illustrations in the form of relevant images; c) Presentation of examples of old and new prose based on local wisdom; d) Presentation of student independent worksheets; e) Presentation of terms or the translation of the Simalungun language into Indonesian; f) Presentation of bibliography.

5. Based on the feasibility aspect of linguistic assessment, students need independent teaching materials, namely: a) The language used is easy to understand; b) The language structure is in accordance with the rules of the Indonesian language; c) The language used is communicative.

6. Based on the feasibility aspect, students need independent teaching materials, namely: a) titles and types of writing are varied and interesting; b) The images presented are of good quality and clear; c) The type of paper used is soft cover and A5 paper size; d)

The colors on the white and illustrated covers are creatively and attractively designed.

In the next stage, the developed module is then validated by a team of material experts, design experts, responses from Indonesian language education study program lecturers, and student responses. After being declared valid, the developed module was tested on 3 students called individual trials, then 9 students were called small group trials and finally tested on 36 students called limited field trials. After obtaining the trial data, it was analyzed conceptually and then revised. The final result obtained is the moduledeveloped in pthe lesson has been declared valid.

\subsection{Feasibility of Teaching Materials for Prose Appreciation Based on Local Wisdom}

Validation material on the product is intended to determine the opinion of material experts about the appropriateness of the content, the feasibility of presentation and language assessment. Design validation of the product is carried out to improve the display quality of the module being developed. The results of research on product feasibility are as follows.

1. The results of module validation by a team of material experts are obtained as follows.

a. The content feasibility aspect obtained an average score of $93.75 \%$ in the very good category.

b. The presentation feasibility aspect obtained an average score of $91.34 \%$ in the very good category.

c. The language assessment aspect obtained an average score of $95.19 \%$ in the very good category.

2. The results of module validation by learning design experts on the graphic aspect concluded that the learning design developed was in the "very good" criteria with an average percentage of $92.08 \%$. 
Based on the results of the analysis carried out by the validator on the material expert validation questionnaire and design expert validation, the description of each validated aspect.

Table 1. Validation Results of Material Experts and Design Experts

\begin{tabular}{|l|l|l|l|}
\hline No. & Rated aspect & Average Percentage & Criteria \\
\hline 1 & Content eligibility aspect & $93.75 \%$ & Very good \\
\hline 2 & $\begin{array}{l}\text { Presentation feasibility } \\
\text { aspect }\end{array}$ & $91.34 \%$ & Very good \\
\hline 3 & $\begin{array}{l}\text { Aspects of language } \\
\text { assessment }\end{array}$ & $95.19 \%$ & Very good \\
\hline 4 & Design & $92.08 \%$ & Very good \\
\hline
\end{tabular}

Based on the table above, it can be concluded that the results of the validation on the aspect of content feasibility by the validator obtained a value of $93.75 \%$ in the very good category. However, of the 16 statements there is 1 statement with a sufficient category, 6 statements in a good category, and 9 other statements are categorized as very good. The validation of the presentation feasibility aspect by the validator obtained a value of $91.34 \%$ with the very good category. However, of the 13 statements there were 3 statements in the sufficient category, 3 statements in the good category, while the other 7 statements were categorized as very good. Validation of the language assessment aspect by the validator obtained a value of $95.19 \%$ with the very good category. However, of the 13 statements, there was 1 statement in the sufficient category, 3 statements in the good category, while the other 9 statements were categorized as very good. Design validation by a team of design experts scored $92.08 \%$ in the very good category. However, of the 30 statements, there were 5 statements in the sufficient category, 9 statements in the good category and 16 other statements in the very good category.

3. The results of the Individual Trial Module Response to the developed module concluded that the developed module was included in the "very good" criteria with a total average percentage of $82.50 \%$. Individual trials were carried out to find out students' initial responses to identify product deficiencies of the products developed prior to the small group trial. This means that the local wisdom-based Prose Appreciation module that has been developed is in accordance with the needs of students.

4. The results of the module response in small group trials conducted on nine students with high, medium and low abilities, showed that the module developed was included in the "very good" criteria with a total average presentation of $90.27 \%$. Based on these results, it was concluded that there was no need for revision so that it could be continued to the next trial stage, namely limited field trials.

5. The results of the module response to the limited field group trial showed that the module included the criteria "very good" with an average score percentage of $94.02 \%$. 


\section{Conclusion}

This research produces an independent teaching material product in the form of a local wisdom-based module on the material of appreciation of prose in the literature appreciation course. Local wisdom was chosen to help students appreciate prose from the level of enjoying to producing prose in the form of short stories. In addition, it also increases students' knowledge, understanding and love of local wisdom that surrounds campus life and daily life in Pematangsiantar city. This module has been validated by material, language, and design experts. This module is designed according to the needs of students and can be used as independent teaching materials without lecturer instructions. The appropriate modules will be implemented and used in the lecture process on prose appreciation material. Suggestions for further module development can be made for the entire material so that it is not only a supporting independent teaching material but can be a teaching material as the main source of learning based on local wisdom in the wider Pematangsiantar city.

\section{Acknowledgements}

Thanks to: Directorate of Research and Community Service, Directorate General of Research and Development Strengthening Ministry of Research, Technology and Higher Education for research funding assistance.

\section{Reference}

Daryanto and Dwi C. (2013). Learning Tool Development. Yogyakarta: Gravanedia. Ministry of National Education. (2008). Instructional Material Development Guide. Jakarta: Depdiknas

F. Ferdianto, S. Setiyani. (2018). Development of Teaching Materials for Learning Media Based on Local Wisdom for Mathematics Education Students. National Journal of Mathematics Education, 2 (1).

Junifran, Rosliani. (2020). The Development of Sociocultural Malay-Based on Folklore Teaching Materials for Class $\mathrm{X}$ at SMA N 1 Percut Sei Tuan Deli Serdang. Budapest International Research and Critics in Linguistics and Education (BirLE) Journal Vol 3 (4): 1670-1685.

Lubis, I,G., Adisaputera, A., Dewi, R. (2020). Development of Teaching Materials Based on People's Stories Assisted In the Graphics of 5 th Grade Students Primary School Muhammadiyah 01 Kota Binjai. Budapest International Research and Critics in Linguistics and Education (BirLE) Journal Vol 3 (2): 1083-1093.

Prastowo, A. (2013). Creative Guide for Innovative Teaching Materials. Yogyakarta: DIVA Pres.

Rahyono. FX (2009). Cultural Wisdom in Words. Jakarta: Wedatama Widyasastra.

Tegeh, I Made, et al. (2014). Development Research Model. Yogyakarta: Graha Science. http://pematangsiantarkota.go.id/statis-124/sejarah-kota-pematangsiantar.html accessed on 28 August 2020.

Sugiharto. (2020). Geographical students' learning outcomes on basic political science by using cooperative learning model with Group Investigation (GI) type in State University of Medan, Indonesia, Journal of Human Behavior in the Social Environment, 30:4, 447-456, DOI: 10.1080/10911359.2019.1696261. 